\title{
Surfaces
}

\section{In Memoriam, Fast Forward}

\section{Marc Redfield}

Volume 6, 1996

LES ÉCONOMIES DISCURSIVES DU SAVOIR ET DE LA CULTURE DANS LE SILLAGE DE L'OEUVRE DE BILL READINGS

THE DISCURSIVE ECONOMIES OF KNOWLEDGE AND CULTURE, WITH CONSTANT REFERENCE TO THE WORK OF BILL READINGS

URI : https://id.erudit.org/iderudit/1064856ar

DOI : https://doi.org/10.7202/1064856ar

Aller au sommaire du numéro

\section{Éditeur(s)}

Les Presses de l’Université de Montréal

\section{ISSN}

1188-2492 (imprimé)

1200-5320 (numérique)

Découvrir la revue

Citer ce document

Redfield, M. (1996). In Memoriam, Fast Forward. Surfaces, 6 . https://doi.org/10.7202/1064856ar
Résumé de l'article

Cet essai, en hommage à la mémoire de Bill Readings, examine les voies par lesquelles l'oeuvre de Bill Readings se réfracte et réfléchit sur la vitesse - - une vitesse antérieure à la réflexion, la représentation ou la mesure. La théorisation de Reading sur la temporalité postmoderne est devenue inséparable de son analyse et de sa critique du capitalisme tardif et de l'université. 


\section{In Memoriam, Fast Forward}

Marc Redfield

The Claremont Graduate School

redfielm@cgs.edu

Surfaces Vol. VI.210 (v.1.0A - 15/10/1996) - ISSN:

1188-2492

Copyright for texts published in Surfaces remains the property of authors. However, any further publication should be accompanied by an acknowledgement of Surfaces as the place of initial publication.

\section{ABSTRACT}

This essay, a memorial tribute to Bill Readings, examines ways in which Readings' work refracts and reflects upon speed-a speed "prior" to reflection, representation, or measure. Readings' theorization of postmodern temporality is shown to be inseparable from his analysis and critique of late capitalism and the university.

\section{RÉSUMÉ}

Cet essai, en hommage à la mémoire de Bill Readings, examine les voies par lesquelles l'oeuvre de Bill Readings se réfracte et réfléchit sur la vitesse - - une vitesse antérieure à la réflexion, la représentation ou la mesure. La théorisation de Reading sur la temporalité postmoderne est devenue inséparable de son analyse et de sa critique du capitalisme tardif et de l'université. 
What follows moves very fast, in order to raise a question

about the modernist temporality of accelerated revelation.

- - Bill Readings, "Milton at the Movies"

In the beginning, Jacques Derrida wrote about a decade ago, jump-starting a lecture on "nuclear criticism" at Cornell University -in the beginning, there will have been speed. Not a Word, nor, as for Faust, an act: "No! At the beginning-faster than the word or the act-there will have been speed, and a speed race between them" (22). He uncoiled this elegant technoparody in ways I have no time to do justice to here. He was playing, certainly, with the uncertain difference between knowing and doing, or between constative and performative language; he was commenting on the possibility and discourse of nuclear warfare, and the reality of the arms race. The reality of this last has everything to do with a certain infinite and radical textuality. The nuclear phenomenon is "fabulously textual, through and through": not only does nuclear weaponry depend "more than any other weaponry in the past, it seems, upon structures of information and communication" (23); not only is all this speed putatively rhetorical in thrust (aimed at "dissuasion" or "deterrence"); but the full reality of this war is unimaginable, representable only as fantasy, fiction, rhetorical figure. It is the death no socius can accommodate, no mourning anticipate, or history contain. A fabulous fictionality drives the stockpiling of knowledge and weaponry, the calculation of risk. Is it new, this speed marking this vast, senseless process of technoscientific capitalization, or is it rather "the brutal acceleration of a movement that has always already been at work?" (21). Derrida leaves the question hanging, urgently. If it is always already speeding by, this speed without measure, it's also unheard of. It resists the calculations of knowledge or brinksmanship. There is no apocalypse -no revelation, no "now"-at the heart of this nuclear death. One must move both quickly and slowly here.

Trying to write about Bill Readings, I've been drawn to this essay of Derrida's, not, I hope, because of the apocalyptic lure of the object of its anti-apocalyptic analysis, but because this text's virtuoso play on "speed" has seemed to touch something essential in my memory of Bill. Bill knew about speed. He knew it was important, 
these days, to move both quickly and slowly. By this I emphatically don't mean to imply that he knew he didn't have much time. No one has time for a destiny these days. If Bill's career accelerated hugely in the two or three years prior to his tragic death in 1994, this was simply because his energy and talent had accumulated increasing institutional force. He was always doing a double armful of things at once; and those who knew him know that professional pursuits were always only a small, sane portion of the things Bill would be up to. Yet the professional activities matter deeply here; this online journal, among other things, came into existence as one of them; and we are writing these tributes to Bill in it because he had speed.

I hope it is obvious that I do not mean haste-quite the opposite; more on that in a moment-and I don't even mean the sheer velocity of a career, though Bill was never one to imagine or pretend that one can or should evade the conditions of intellectual labor in the modern university. His career was of course meteoric. He broke through the book barrier in '91, and after that the books and articles seem to come in a blur, not to mention the journal Surfaces, the Humboldt seminar, the special issue of $O L R$ (which I haven't yet seen) and who knows what else. But let me step on the gas and say right away that Bill's work was about speed, the predicament of speed, which he analyzed in various ways, often under the name of what he called, after Lyotard, the postmodern:

We have all heard the word postmodernism. It is in the news. And yet it cannot be just the news, what is new, what is modern. It must be in some sense after the new, post, and yet must at the same time not yet have arrived, must have got caught in the post.... For us, the postmodern marks a temporal aporia, a gap in the thinking of time that is constitutive of the modernist concept of time as succession or progress. This is something we feel strongly about. (I, 5-6)

The postmodern condition is not simply the same thing as the nuclear one; but there is an overlap of speed, the two are confused always already (and that's fast). As a buckle or fracture in modernist time, the postmodern is not an era; but neither, as we have seen, is the nuclear, when posed as a question of speed. Both have a relation to late capitalism that cannot be reduced to the homogenous temporality of the modern, which is to say the accountable temporality of capitalism. 
Postmodernism names the pressure of an "unaccountable time" at work in the modernist temporality of capitalist accumulation (MM, 92). Capital stockpiles time-labor time-by hurling itself headlong into the void, as Milton's God hurls Satan: "Time can only be 'stored' as more capital. To store time as capital, however, does not balance things, but speeds them up more" (MM, 91). The capitalist machine is hardwired to a bomb. Speed is the madness of capital's rationalizations. In or as the postmodern, this madness becomes legible.

Bill was consequently suspicious of a certain easy suspicion about speed. Suspicion becomes easy when it turns into a reflex of condemnation or celebration, as can so easily happen, these days: "Commodities circulate in a dizzying vortex of speed; simulacra hollow out a vast abyss in the place of the real; Elvis is everywhere. Jameson calls this a hysterical sublime; Baudrillard stays cool" (SP, 409). The unprecedented ferocity of late capitalism certainly must never for a moment be underestimated. Like the nuclear threat, capitalist rationalization saturates the West's postmodern sublime and undergirds its gruesome manifestation as "fun." "Fun replaces the mixture of pleasure and pain; Disney simulation offers a roller coaster ride instead of nuclear annihilation as the presentation of the idea of technology. The ups and downs of the roller coaster as we journey through the molecule replace the terror of the splitting of the atom" (SP, 414). But precisely because capitalization in all its forms depends upon a speed without measure, the "radical indeterminacy of the sublime" offers us a chance: the chance of "a sublime politics," a "politics of dissensus" (SP 411, 423).

Bill's work was always consciously political in orientation, and always fundamentally committed to a rethinking of the political. From his earliest publications to his forthcoming The University in Ruins, he pursued "the deconstruction of politics": the deconstruction, that is, "of the opposition of politics to textuality, an opposition traditionally conceived in terms of that of action to language, of the rhetorical to the literal" (DP 225). The fabulous textuality of speed is nothing if not "real." And its reality is enabled by an indeterminable rhetoricity in which Bill located the promise of an "accountability beyond accounting" (UWC 481), a community in excess of communication. Drawing on Blanchot, Bataille, and Nancy as well as Lyotard, he called for a pragmatism without piety or ground, a politics which "lies in a fragile and fugitive attention to events, to the unforseen solidarity of the oppressed and the unimaginable imagination of militants" (F, xiv). His 
work increasingly sought to engage the political as a limitless responsibility to the other, which we inherit as the possibility of speaking or thinking at all. The political becomes the invocation of "an incalculable difference, an unrepresentable other" (PPP, 187). The social bond becomes "the sheer fact of a language that comes to us from others, the sheer otherness of other people" (SP 420). A stray wire in Bill's text connects him for a moment to texts signed Avital Ronell (among others), and he thinks of speech, and the politics of speech, as a party-line telephone: "it has rung, we are speaking, but we do not know exactly why or to whom" (SP 420). Technology capitalizes on an anonymity which nonetheless outstrips capitalization. Communication erects its marvels upon differences and differends to which it is our infinite responsibility to bear witness. "[T]aking up responsibility for one's actions involves an obligation which exceeds the subject's capacity to calculate, which does not understand responsibility as a matter solely for the subject, a matter tha can be calculated by a more self-conscious subject" (UWC, 483).

Again and again Bill's assumption of this responsibility returns him to the aporia of time. The alterity of the revolutionary event occurs in, or better, as "revolutionary time: the noncumulative time of minoritarian struggles, which resist history, refuse the dialectic of imperial time" (F, xv-xvi). The task of the historian becomes the assumption of a haunted temporality, a present disrupted by "the persistence of the past as remainder or ruin" (WDRB, 286). The ethics of pedagogy engage "the strange temporality of education," which positions students as both belated and ahead of themselves, born too late to inhabit a culture into which they have nonetheless been precipitously thrown (F, xvii). The temporality of reading and the time of thought occur in and as "an insistence on the literary event as irreducible to an exchangeable moment": the future anterior of "unaccountable time" (MM, 92; cf. IL, 138). One sees that all this fast-forwarding has gotten us back to the postmodern. But it should be a little more clear at this point that speed is not haste. Speed is incalculable; its demand on our attention is exhaustive.

In our techno-managerial age the institutions we inhabit lie in ruins long before any bombs can fall. The university, Bill reminds us, is a blackened shell. It has taken major hits while the nation-state has been rushing to rubble. "[T]he decline of the nation-state as the primary instance of capitalism's self-reproduction has effectively voided the social mission of the modern 
university" (UWC, 466). Culture has lost its content, and the university its rationale. No one these days can be the hero of the story of the University, which is why, Bill says, he is writing his big book ahead of time, in good speed: "There is no point in my waiting. I am not going to become Jacques Barzun; the University system does not need such subjects any more" (UR, ch. 1). That the University no longer needs embodiment in a man of culture is not necessarily a bad thing. Nor is it simply a good thing: the University has been developing rationalizing mechanisms in the absence of rationale.

Downsizing, expanding, diversifying and centralizing, the University is becoming what Bill called-drawing on press reports, on middle-class teen and twentysomething slang, and on administrationspeak itself-a University of "excellence." The University is becoming a managed corporation. It was once an ideological state apparatus, but no longer; the Althusserian analysis has fallen a little behind, since the University now offers its consumers an excellence that is neither true nor false, neither selfconscious nor deluded:

As an integrating principle, "excellence" has the singular advantage of being entirely meaningless, or to put it more precisely, nonreferential. All departments of the University can be urged to strive for "excellence," since the general applicability of the notion is in direct relation to its emptiness. As a purely internal unit of value, it shares with Machiavellian virtù the advantage of permitting calculation to be engaged in upon an homogenous scale. In other words, its very lack of reference allows "excellence" to function as a principle of translatability between heterogenous language games. (FHCP, 168)

More and more of us teach at excellent universities. My own institution, the Claremont Graduate School, has just been "designated" a "Center of Academic Excellence" by Mexico's Consejo Nacional de Ciencia y Tecnologia, a development that the president of my school greeted as a chance to "bring young emerging Mexican leaders to Claremont to learn and discuss issues important to living in post-NAFTA North America" (The Claremont Graduate School News, 68: 1 (Fall 1995), 1). (Honesty compels me to add that this designation only affects the business, psychology, and political science centers: I do not yet teach in an excellent English Department.) "Excellence" is transnational but seeks to seal itself off from alterity. 
Its criteria emerge within the sheer formality of a closed system: this university or program or teacher or researcher or student measured against those. Radical literary theory can be "excellent" too-which is why, Bill noted, left-wing criticism can be as radical as it wants, so long as it does it excellently.

Later in the same essay Bill refers to the "technological idea of excellence" (FHCP 179, my emphasis). Let me dawdle to unpack that adjective, not just because I've been writing under the nuclear umbrella, but because I think that Derrida understands his meditation on "speed" as an aspect of the question concerning technology, and that versions of that question were constantly on Bill's mind, as I've already so hastily indicated. The discourse of excellence is manifestly technophilic in any number of ways, as the rhetoric of American university administrators demonstrates; but one can trace a fundamental technicity at work in the very formalism of the system itself. Heidegger diagnoses modern technology as Ge-stell, enframing, a process of extracting and stockpiling which transforms the natural world into Bestand, standing-reserve -a state in which objects per se no longer exist in or for themselves, but only in or for something else. There is a twist, however (as always in Heidegger). The evacuation of content within the formality of a (seemingly) total process generates the illusion of a subject of technology. Humanity comes to imagine itself as the will-to-power behind technics, while in fact becoming another sort of standing-reserve. What's the result? A celebration of human excellence; the processing of something which perhaps no longer deserves to be called "humanity" within a technobureaucratic grid.

My own work has pursued links between technics and aesthetics which have in turn led me to see technobureaucracy as a development of aesthetic ideology-as the disfigured literalization of the humanist promise of Schiller's Aesthetic State (see Redfield, ch. 7). Bill generally put less emphasis on aesthetics per se than I do, and more on the the coimplication of the nationstate and the idea of "culture." But in pursuing "culture"'s dereferentialization as "cultural studies" in the global marketplace of late capitalism, he tracked the continuity between aesthetics (as "culture" and the discourse of acculturation) and technics (as the extraction and stockpiling of value): they blend as the rupture of technoculture, which is to say the idea of excellence. "The vast majority of those who speak about the university adopt one of two positions: either nostalgic calls for a return to the Humboldtian ideals of 
community and social functioning, or technocratic demands that the university embrace its corporate identity and become more productive, more efficient" (UWC). The two positions are the two sides of a single coin, precisely because excellence evolves out of aesthetics.

Is there something to be done? Of course, always. There is the infinite, but also punctual and pragmatic, labor of reading, thinking, learning, teaching. There is the vigilance of attention due to the Other. No law or rule can direct this praxis, justify this care for justice, account for the ramifications of accountability. Excellence, like speed, is not simply a bad thing: "the discourse of 'excellence' has its advantages-it is what has permitted the speed with which feminism and African American studies have risen to powerful positions in the disciplinary order" (UWC, 478). Excellence must be transvalued, and can be; alterity has always already filtered into its bookkeeping; "the complex time of thought is not accountable" (UWC, 479).

Let me linger a final moment with an anecdote; Bill was never in too much of a hurry to tell stories; here's a very slender one about him. The first time I met Bill (or almost the first: there had been a coffee at a café a few days earlier) he had come down with laryngitis. It was the fall of 1986. I had just arrived at the University of Geneva, and we were having dinner at the home of another colleague, who like Bill had been teaching at Geneva for several years. The conversation had the information-rich flow which characterizes initial encounters. Bill could manage a rustling sort of whisper, audible only in the rare moments when no one else was speaking. "This silence is not at all typical of Bill," our host Peter de Bolla commented, with perhaps a touch more satisfaction than was decent. (They were, of course, good friends.) Bill still managed to hold up his end of things. To gain attention he resorted to agitated semaphore.

In subsequent months, or indeed, years, that evening was washed into a remote bit of my mind by Bill's glorious flow of talk. It became a recurring memory only after his death, when one played every psychological trick one could with oneself to dodge the reality of loss. His voice will come back again, the mourner hopes secretly, deviously: it must; I remember it so absolutely. 
Anyone who knew Bill will be able to hear his unforgettable voice saying (amid a thousand other things) that one needs to think harder about voice, and memory, and community. One needs to think the absolute singularity of voice, which is always remembered voice: remembered precisely because it is singular, which is to say exposed to and doubled by the utter, devastating loss which is the unspoken truth and ethical imperative of any communality. At no time did Bill have time for pathos, or for indifference.

Our indebtedness to him is unrecoverable, and his voice reminds us that there is work to be done, not least in the university, which is in ruins.

\section{Works Cited}

Derrida, Jacques. "No Apocalypse, Not Now (full speed ahead, seven missiles, seven missives)." Diacritics, 14: 2 (1984), 20-31.

Lyotard, Jean-François. Political Writings. Trans. Bill Readings and Kevin Paul Geiman. Foreword by Bill Readings. Minneapolis: Univ. of Minnesota Press, 1993.

Readings, Bill. "The Deconstruction of Politics." In Reading de Man Reading, ed. Lindsay Waters and Wlad Godzich. Minneapolis: Univ. of Minnesota Press, 1989. 223-43. [DP]

Readings, Bill. "For a Heteronomous Cultural Politics: The University, Culture, and the State." Oxford Literary Review 15: 1-2 (1993), 163-99. [FHCP]

Readings, Bill. "Foreword: The End of the Political." In Lyotard, Political Writings, xiii-xxvi. [F]

Readings, Bill. Introducing Lyotard: Art and Politics. London: Routledge, 1991. [IL]

Readings, Bill. "Milton at the Movies: An Afterword to Paradise Lost." In Postmodernism Across the Ages, 88-106. [MM]

Readings, Bill. "Pagans, Perverts, or Primitives? Experimental Justice in the Empire of Capital." In Judging Lyotard. Ed. Andrew Benjamin. London: Routledge, 1992, 168-91. [PPP] 
Readings, Bill. "Sublime Politics: The End of the Party Line." Modern Language Quarterly 53: 4 (1992), 409-25. [SP]

Readings, Bill. The University in Ruins. Cambridge: Harvard Univ. Press, 1996. [UR]

Readings, Bill. "The University Without Culture?" New Literary History 26: 3(1995), 465-92. [UWC]

Readings, Bill. "When Did the Renaissance Begin? The Henrician Court and the Shakespearian Stage." In Rethinking the Henrician Era: Essays on Early Tudor Texts and Contexts. Ed. Peter C. Herman. Urbana: Univ. of Illinois Press, 1994, 283-302. [WDRB]

Readings, Bill. "Why is Theory Foreign?" In Theory Between the Disciplines: Authority/Vison/Politics. Ed. Martin Kreiswirth and Mark A. Cheetham. Ann Arbor: Univ. of Michigan Press, 1990, 77-97. [WTF]

Readings, Bill, and Bennet Schaber. "Introduction." In Postmodernism Across the Ages, 1-28. [I]

Readings, Bill, and Bennet Schaber, eds. Postmodernism Across the Ages: Essays for a Postmodernity That Wasn't Born Yesterday. Syracuse: Syracuse Univ. Press, 1993.

Redfield, Marc. Phantom Formations: Aesthetic Ideology and the Bildungsroman. Ithaca: Cornell Univ. Press, 1996.

Accueil Surfaces | Table des matières | Recherche Surfaces Home Page | Table of Contents | Search

PUM | Livres | Revues | Publications électroniques | Vente et distribution 